\title{
Physical modelling of superimposed tectonic events in the Volta Redonda Basin, Southeastern Brazil
}

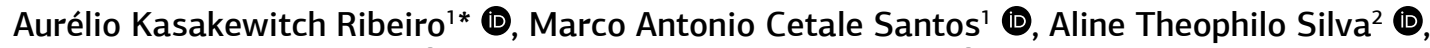 \\ Fernanda Silva Lourenço² (D), Sílvia Cristina Barroso Negrão² (1)
}

\begin{abstract}
This paper presents the results of a new approach based on sandbox models to the understanding of the tectonic evolution of the Volta Redonda Basin, southeastern Brazil. Those models were designed to replicate the overlapping process of two of the four superimposed tectonic events identified in the Volta Redonda Basin: the first one, a rifting event with NW-SE extension direction that created the basin, and the subsequent E-W sinistral transcurrent tectonics. The boundary conditions for the models were set from the geological premises described in previous works, which resulted in the current conceptual geological models of the study area. The sandbox models were composed of alternating layers of colored sand, deposited on two pieces of acetate or cardboard sheets, which acted as pre-existing basement structures. Once completed, the models were cut and photographed to allow observation and interpretation of the resulting internal structures. Moreover, the interpretations maintain similarities with adopted conceptual models and permit conclusions about structures previously identified in other works. Finally, the consequent structural framework exposes the effects of structural reactivation and Basin geometry changes due to the superposition of deformational events and matches with the general structural aspects identified in field studies.
\end{abstract}

KEYWORDS: analogue modelling; sandbox model; Volta Redonda Basin; extensional tectonics.

\section{INTRODUCTION}

In the last forty years, the scientific understanding of the geology of the Volta Redonda Basin has improved a lot. Since the work of Riccomini (1989), authors have studied various geologic phenomena in the area. The most recent studies in the basin, including structural and stratigraphic characterization (Maciel 2016) to geologic numerical modelling of fault zones genesis (Rodrigues 2016), reflect a new and important interest on understanding the role of deformation on the quality of poorly consolidated sandstones reservoirs. The focus on the Volta Redonda Basin is due to the good exposition of rocks of the Resende Formation, considered an analogous geomaterial to some important Maastrichtian hydrocarbon reservoirs at the neighbor Santos, Campos and Espírito Santo offshore basins. However, it is natural that diverse scientific gaps still need to be filled. One example is the understanding of the boundary conditions that resulted in the present configuration of the Volta Redonda Basin, supposedly related to the reactivation of basement structures (Riccomini 1989, Negrão 2014).

The geometry of the Volta Redonda Basin is related to preexisting weakness zones in the basement, as well as to the

\footnotetext{
${ }^{1}$ Universidade Federal Fluminense - Niterói (RJ), Brazil.

E-mails: aureliokr@id.uff.br, marcocetale@id.uff.br.

${ }^{2}$ Centro de Pesquisa e Desenvolvimento/GEOTEC, Petrobras - Rio de Janeiro, (RJ), Brazil. E-mails: alinet@petrobras.com.br, scnegrao@petrobras.com.br, fernandalourenco@petrobras.com.br ${ }^{*}$ Corresponding author.
}

(c) 2020 The authors. This is an open access article distributed under the terms of the Creative Commons license. orientation of deformational stress imposed by successive tectonic phases. It's has been determined by K-Ar absolute ages on volcanic rocks that the basin was originated in the Paleogene (Riccomini et al. 1983), when its main sedimentary infills were deposited. Furthermore, successive deformational events took place from the Neogene to the present days. Riccomini (1989) argued that its origin and tectonic evolution might be related to the Continental Rift of Southeastern Brazil (Rift Continental do Sudeste do Brasil - RCSB). In this way, it is possible to identify faults that inherit the attitude of its rifting phase, as well as the interference caused by the posterior tectonic phases identified in the Volta Redonda Basin, reactivating previous stablished structures.

This is an example of pre-existing structures controlling the evolution of rift basins. McClay and White (1995) completed a detailed study on the progressive evolution of rift systems due to the angular variation between pre-existing structures and the imposed stress. This question was the main theme of diverse researches on structural geology (McClay et al. 2002, Maurin and Guiraud 1993, Corti et al. 2003, Corti 2012). Moreover, it is necessary to investigate the circumstances that resulted in the emergence and reactivation of structures through successive tectonic events identified in the study area. In this context, Cobbold et al. (2001) documented evidence of structural reactivation in the Santos and Campos basins (SE Brazil). In addition, Keep and Harrowfield (2005) investigated the structural reactivation of basement structures of passive margins. Therefore, the object of this work is to describe the structural evolution resulting from the superposition of a phase of strikeslip movement over a phase of extension in the Volta Redonda 
Basin in order to compare the results to the conceptual models presented in the literature. These are the earliest events identified in the Volta Redonda Basin (Riccomini 1989, Sanson et al. 2006, Negrão et al. 2015). Good results were reached through analogue sandbox models of the deformational events, built with carefully scaled boundary conditions in order to create a credible replica of the natural prototype.

\section{GEOLOGICAL CONTEXT}

The Volta Redonda Basin is located around the middle valley of the Paraíba do Sul river, in the State of Rio de Janeiro (Fig. 1A), southeastern Brazil. It constitutes a part of the RCSB (Riccomini 1989), established on Proterozoic/Eopaleozoic basement rocks of the central segment of the Ribeira belt, one of the largest Neoproterozoic Brasiliano orogenic systems of Brazil (Almeida et al. 1981) (Fig. 1B).
According to Heilbron et al. (2004), the Paraíba do Sul Group is the outcropping basement unit most greatly expressed in area of the Volta Redonda Basin. It is composed of lithological assemblages associated with upper amphibolite facies metamorphism. It mainly contains banded biotite gneisses at the base, micaceous and schistose gneisses in the intermediate portion, and intercalations of (garnet)-biotite gneisses with schist and pelitic gneisses at the top.

The structure of the basement is formed by elongated bodies of rock with a preferential NE-SW orientation (Heilbron et al.2004). Negrão (2014) and Brêda et al. (2018) presented a study of the lineaments present in this region. The analyses were carried out with the SRTM/NASA Digital Elevation Model (DEM). In the basement area around the Volta Redonda Basin, lineaments equal to or greater than $10 \mathrm{~km}$ were identified and observed to follow the structural configuration of the Ribeira belt (NE-SW). Furthermore, in the Cenozoic

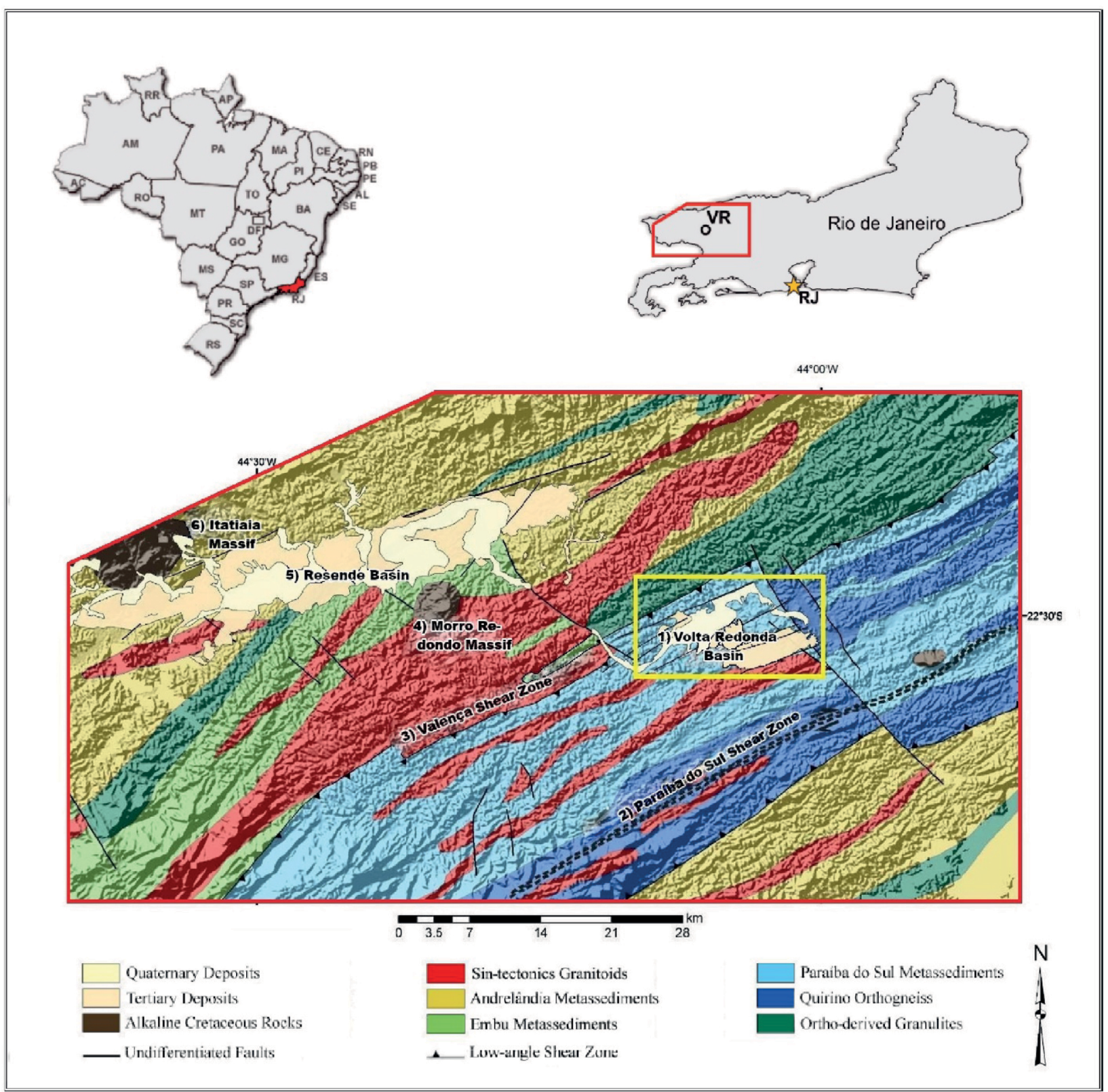

Figure 1. (A) Location of the study area. (B) Simplified geologic map of the central segment of the Ribeira Band. This region contains the Resende Basin and Volta Redonda Basin (black rectangle). (1) Volta Redonda Basin; (2) Paraíba do Sul Shear Zone; (3) Valença Shear Zone; (4) Morro Redondo Massif; (5) Resende Basin; (6) Itatiaia Massif. Modified from Sanson (2006). 
Deposits Domain, lineaments shorter than $10 \mathrm{~km}$ with principal orientations $45^{\circ} \mathrm{N}-90^{\circ} \mathrm{W}$ were identified. The continuity of these NW-SE and E-W structures shows the influence of recent tectonic events on Eopaleozoic/Proterozoic rocks.

The origin and evolution of the Volta Redonda Basin are strictly related to the events that took place in the RCSB. In this way, the origin of the basin is related to extensional stresses oriented NW-SE, during the Paleogene (E1) (Fig. 2) (Riccomini 1989). According to the author, this tectonic event led to the development of the center segment of RCSB, reactivating previous structures with ENE-NE orientation dipping towards the coast.

Other tectonic events identified in the RCSB posterior to its opening modified the landscape and altered the then stablished structural configuration (Riccomini 1989, Sanson et al. 2006, Negrão et al. 2015). These events include (Fig. 2): sinistral E-W transcurrent movement during the Miocene (TS); dextral E-W transcurrent movement during the Pleistocene (TD); and NW-SE extension during the Holocene (E2).

The NE-SW normal faults and NW-SE reverse faults identified on RSCB are related to the sinistral transcurrent movement that took place on the Neogene. There were also identified sinistral transcurrent faults that were associated with local transpression zones that led to uplifts in the studied area (Riccomini 1989, Negrão 2014).

The posterior dextral transcurrent movement is responsible for the NW-SE normal faults and NE-SW reverse faults, formed during the Pleistocene. Finally, it's proposed that the
NW-SE extension during the Holocene is responsible for the current segmentation of the depocenters and for the sediment distribution of the basins nowadays (Riccomini 1989, Negrão 2014).

It is also proposed that the balance between far-field stress related to the opening of the Atlantic Ocean (ridge-push) and the subduction of the Nazca plate beneath the South American continent (slab-pull) controlled the orientation of local stress during tectonic events expressed in the RCSB, including the Volta Redonda Basin (Riccomini 1989).

Sedimentary infilling of the Volta Redonda Basin includes the Resende and Pinheiral Formations, both deposited during the rift phase (E1). They are generally composed of conglomerates and poorly consolidated sandstones of a quartz-feldspathic composition, occasionally intercalated with pelitic intervals (Riccomini 1989, Negrão et al. 2015). It is important to highlight the presence of lava spill deposits of ultramafic alkaline rocks (the Casa de Pedra basanite), from which it was possible to obtain absolute dating data using the methods K-Ar $(43.8 \pm 6.2$ e $41.7 \pm 5.7 \mathrm{Ma})$ and Ar-Ar $(48.3 \pm 0.5$ e $47.6 \pm 0.7 \mathrm{Ma})$. These volcanic rocks constrain the age of the sediments. However. their stratigraphic positioning remain contentious (Melo et al. 1983, Riccomini 1989, Sanson et al. 2006). Finally, preserved sediments of the Ribeirão dos Quatis Formation, that are older than the opening event (Sanson et al. 2006, Riccomini et al. 2004, Negrão 2014, Negrão et al. 2015), can be found on the top of the hills along the limit of the basin.

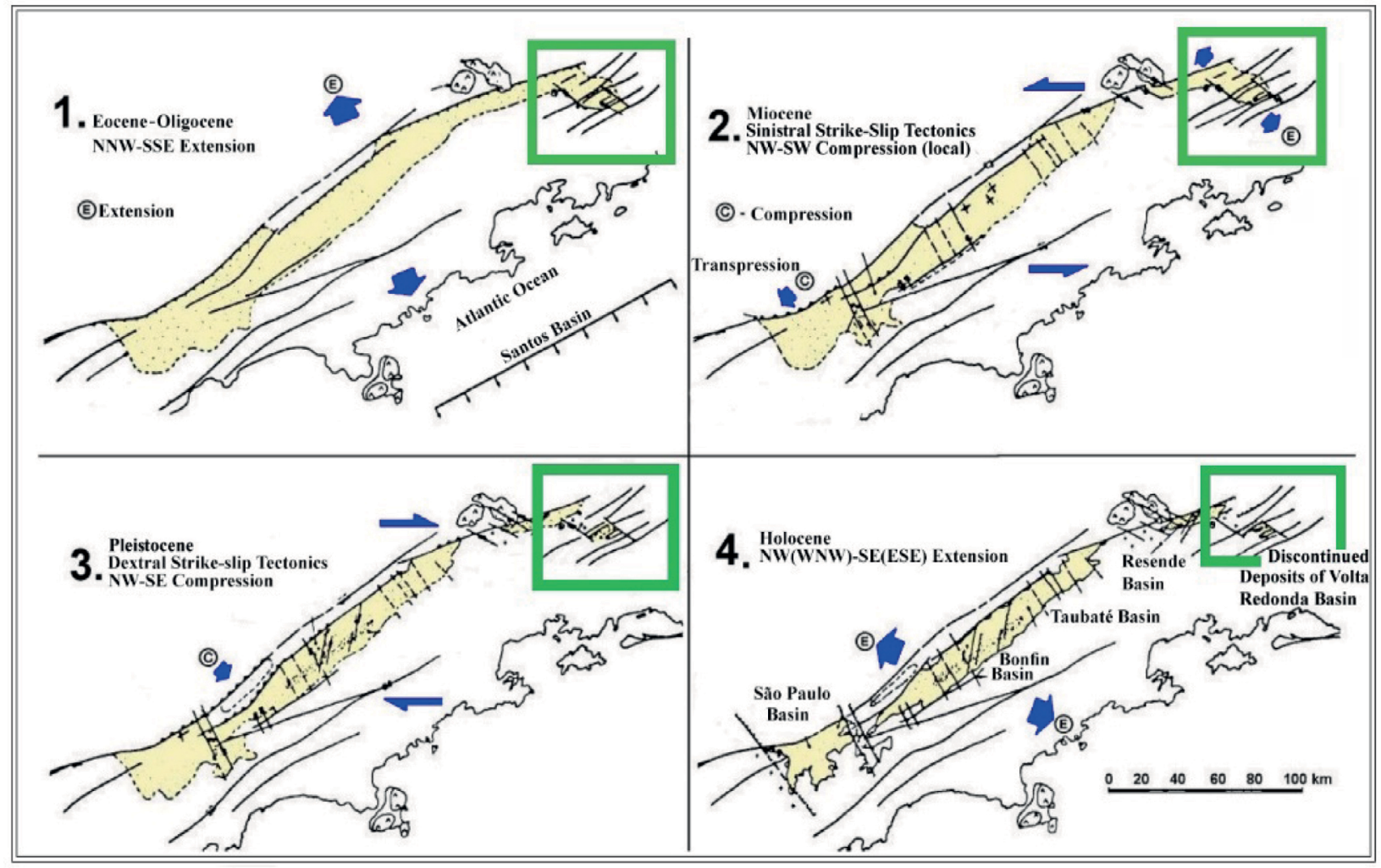

Source: modified from Riccomini (1989).

Figure 2. Tectonic phases identified on the Rift Continental do Sudeste do Brasil (Riccomini 1989). The region where the Volta Redonda Basin was located, highlighted by the green rectangle, presents a slight variation in the angle of the adjacent structures in relation to the general structure of the Rift Continental do Sudeste do Brasil. 
The sedimentary packages of the Volta Redonda Basin present a discontinuous distribution (Fig. 3A) (Sanson et al. 2006, Negrão 2014). The principal depocenter of the region, the Casa de Pedra graben, is approximately $9 \mathrm{~km}$ long in the NE-SW direction and $3 \mathrm{~km}$ long in the NW-SE direction. The depth of the basement has not been stablished by the time of publication of this study. However, magnetotelluric studies estimated a maximum thickness of $200 \mathrm{~m}$ for sediments along the northern border of the Casa de Pedra graben (Fig. 3B) (Padilha and Vitorello 1992).

The most recent conceptual models for the configuration of the Volta Redonda Basin by the end of its rifting phase (Fig. 4A) and for its current configuration (Fig. 4B) are from Negrão (2014) and Negrão et al. (2015). The models were constructed based on field data collected by the author and interpretation of topographic data from a composite section across the regions of the Casa de Pedra graben, Jardim Amália, the Usina graben, and the Belmonte area. The author proposes an initial hemi-graben geometry whose master fault is located in the SE, where the thickest sedimentary packages would be located. In these models, it is possible to point out the region that will become the Jardim Amália area, which has been a high-standing structure in the basin since its opening. The present configuration suggests a partial polarity inversion in the Paleogenic depocenters of Usina graben and Jardim Amália.

Finally, one must emphasize that the main objective of the sandbox models built for this study is to test the viability of the conceptual models described above.
Furthermore, the sandbox models seek to reproduce the current configuration proposed for the Volta Redonda Basin (Fig. 4B) through overlapping two deformational events identified in the basin.

\section{MATERIALS AND METHODS}

Analogue modelling is a practical and visual method of representation, at laboratory scale, of geologic phenomena in nature, paying respect to the frictional parameters of the utilized materials and the necessary boundary conditions. Several authors have already demonstrated the effectiveness of sandbox models in representing geometries and structures identified in nature, particularly in extensional systems (McClay and White 1995, McClay et al. 2002, Corti 2012, Carvalho 2017).

During this study, three models were adopted with the intention of reproducing the two earliest tectonic phases in the Volta Redonda Basin. The first two of them were designed to test each phase separately: one model to simulate asymmetric rifting with high obliquity $\left(\alpha=82^{\circ}\right)$ and another one to simulate sinistral extension of low obliquity $\left(\alpha=26^{\circ}\right)$, in order to produce an oblique sinistral-normal movement of the previous stablished faults. The third one was selected as the best representation of the idealized geometry of the conceptual models of Negrão et al. (2015). In other words, a model that simulated the superposition of asymmetric rifting of high obliquity $\left(\alpha=82^{\circ}\right)$ with sinistral strike-slip movement of low obliquity $\left(\alpha=8^{\circ}\right)$. For simplicity, these models will be referred as Model 1, Model 2, and Model 3, respectively. The adopted

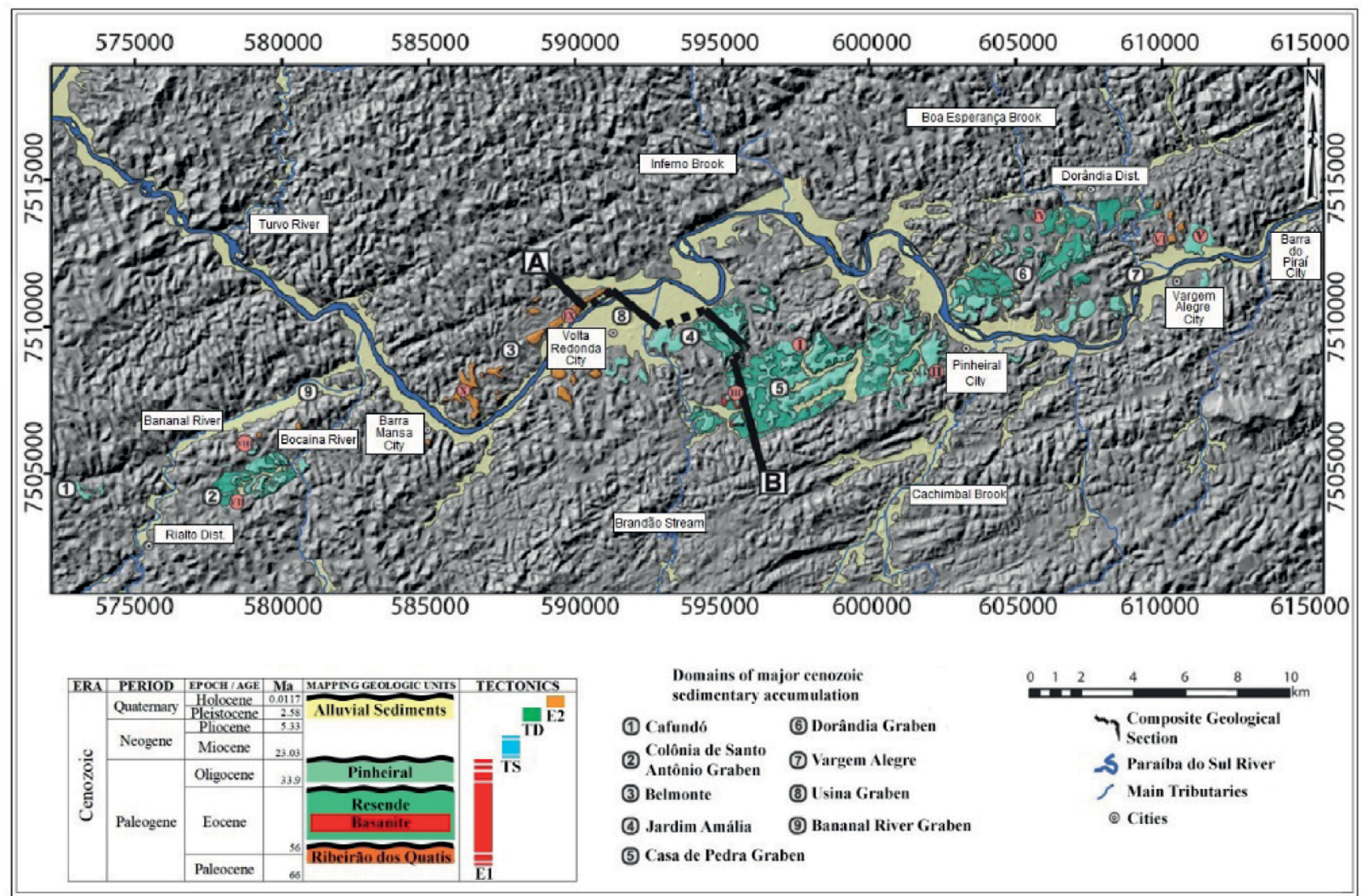

Figure 3. Geologic map of cenozoic sediments overlying a Digital Elevation Model of the Volta Redonda Basin. Modified from Negrão et al. (2015). The black segmented line A-B over the map represents the surface trace of the composite geologic section presented further in Figure 4. 
angles refer to the stress field orientation during the two earliest phases of deformation in the Volta Redonda Basin, highlighted in Figure 2.

The usage of analogue materials in geological modelling is only justified due to the physical dimension analysis supporting it (Davy and Cobbold 1991). In this context, the material used to fill the models was colored dry quartz sand. This material is commonly used to reproduce brittle, supracrustal geologic processes and represents, in the presented models, the basement rocks and the sedimentary infill of the basin, distinguished by their colors. The dry quartz sand used in the experiments is characterized by an average grain size fraction of $0.35 \mathrm{~mm}$. The frictional parameters of the sand (i.e., the internal angle of friction and cohesion of quartz sand) are presented and discussed by Carvalho (2017). The previously mentioned author determined some of the frictional properties of the sand. The ring-shear test carried out by the author corroborated that the different colors adopted for the sand do not interfere in the structural modelling of the structures. For the colorless sands, the same author established its friction angle of $38.77^{\circ}$, slightly greater than the same parameter measured in the colorful sands.

During the conceptualization of Models 1 and 2, the idealized workflow described by McClay and White (1995) was followed (Fig. 5). Consequently, the models were constructed in acrylic boxes $(35 \times 37 \times 15 \mathrm{~cm})$ with three fixed walls and one wall coupled to a motor, with a basement represented by acetate sheets previously cut and oriented oblique to the motor in order to simulate the pre-existing discontinuity of the natural basement (Figs. 5A and 5C). These sheets, when coupled to the motor, exert the function of localizing the rift opening and conditioning its opening according to the orientation of the prototype stress field. Dry sand was used to represent sedimentary infilling of the prototype, with a total thickness of $7.2 \mathrm{~cm}$ alternating between thicker white layers $(1.5 \mathrm{~cm})$ and thinner black layers $(0.3 \mathrm{~cm})$. Studies that used similar techniques to represent the influence of basement on deformation are abundant (Clemson et al. 1997, Cappelletti et al. 2013, Tong et al. 2014), corroborating its applicability in the reproduction of the desired geometries. Deformation advanced according to the movement of the motor along an arbitrary path and varied according to the model. During the opening process, alternating layers of red and blue sand were deposited, with the intention of simulating the processes of syntectonic sedimentation. This deposition occurred without stopping the motors, along the entire surface of the model, using a funnel and sieves with 300 and $425 \mu \mathrm{m}$ openings, the same that were used for the deposition of the layers that composed the basement.

After deformation ended, a layer of white sand was deposited with the objective of protecting the structures at the top of the model during the humidification process, which was realized with a water sprayer. After 24 hours, cuts were made orthogonal to the previously established discontinuity in the acetate sheet. Parallel cuts were made, with $2 \mathrm{~cm}$ of space between them, and photographed for later interpretation.

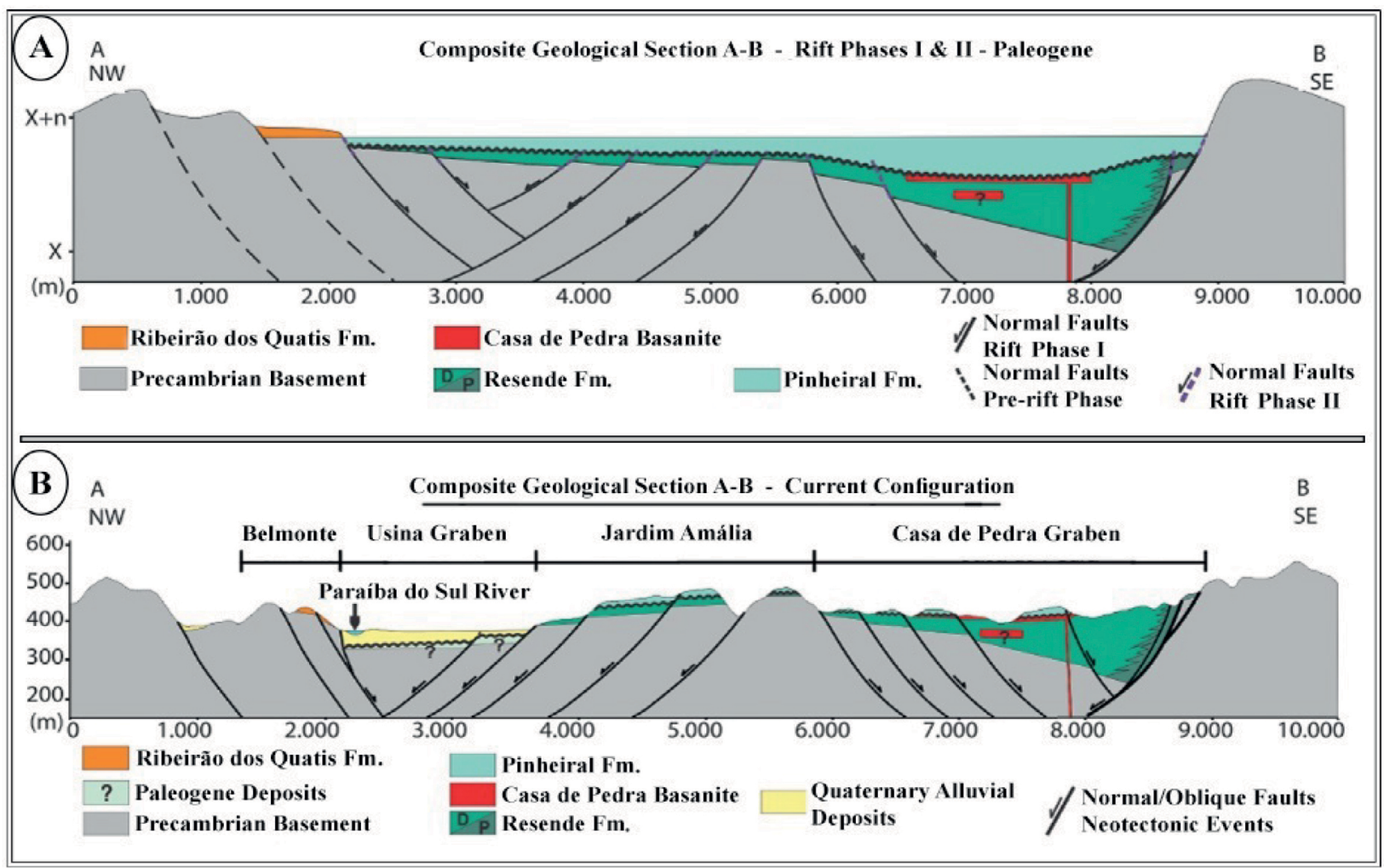

Source: modified from Negrão et al. (2015).

Figure 4. (A) Composite geologic section representing the configuration of the Volta Redonda Basin during its opening (E1). (B) Composite geologic section representing the present configuration of the Volta Redonda Basin. The segments that compose these sections are available, in plan view, in Figure 3A. 
Model 3 has a different layout compared with Models 1 and 2 (Fig. 6). Its dimensions were increased to prevent eventual collapse, and it was constructed directly on the table instead of on an acrylic base. The acetate sheet was replaced by cardboard. The box was constructed with mobile walls (i.e., all walls could be uncoupled during modelling) with increased dimensions of $50 \times 37 \times 15 \mathrm{~cm}$ (Figs. 6A and 6B). For comparison, sand was deposited with the same thicknesses described for Models 1 and 2 (Figs. 6C and 6D). During the first phase of deformation (i.e., the phase of asymmetric, oblique extension), lateral walls were removed to prevent friction between the cardboard sheet and the wall (Figs. 6E and 6F). The lateral collapse of the model was predicted. To minimize damage to the interior of the model, barriers of humid sand were deposited to prevent some probable sand breakout during deformation. Due to the greater amount of time necessary for the conclusion of this model, the rate of deformation was increased from $20 \mathrm{~mm} / \mathrm{h}$ in the previous models to $100 \mathrm{~mm} / \mathrm{h}$. This increase does not represent a negative impact to the configuration previously established for Models 1 and 2, considering that they were formed only of dry sand (a material whose deformation is independent of the parameter of time). Syntectonic layers of red and blue sand were deposited during moments the motors were off, maintaining an interval of deposition for every $1 \mathrm{~cm}$ of deformation.
In total, this phase of deformation encompassed an extension of $5 \mathrm{~cm}$, similar to that foreseen for Model 1 .

The second phase of deformation involved a relative sinistral transcurrent movement (i.e., only one sheet moved while the other stayed immobile) at low obliquity (Figs. 6G and $6 \mathrm{H}$ ). During this phase, there was no deposition of sand. The wall that was stuck to the cardboard during the first round of deformation was removed, following the same protocol for construction of protective dykes to prevent eventual collapse. The other motor was coupled to the free lateral sheet, which generated a nearly orthogonal displacement of the model relative to the acetate structure. Although the orientation of the engine displacement relative to the acetate structure differed from the stress field identified in the Volta Redonda Basin during the Neogene $\left(\gamma=18^{\circ}\right)$, it is believed that this difference will generate only a slightly different result from that presented in this work. This decision, however, was not made arbitrarily. The problem of applying an oblique displacement to the center of mass and the long axis of the substrate sheet would generate irreparable damages to the interior of the model (e.g., non-uniform torque of the sheet, wrinkling of the sheet). In total, this phase of deformation occurred over a distance of $2.5 \mathrm{~cm}$, similar to that foreseen for Model 2. This modelling step ended the superposition of the two deformational events, in which

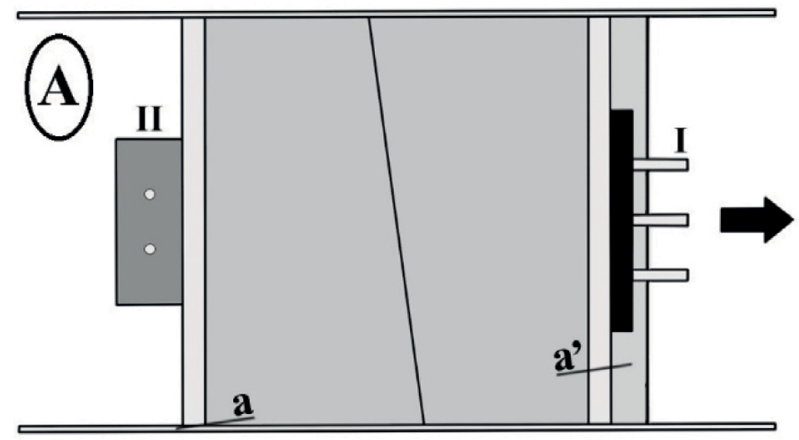

(B)

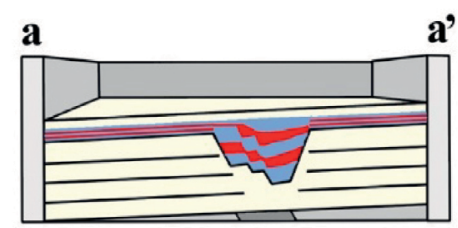

(D)

b
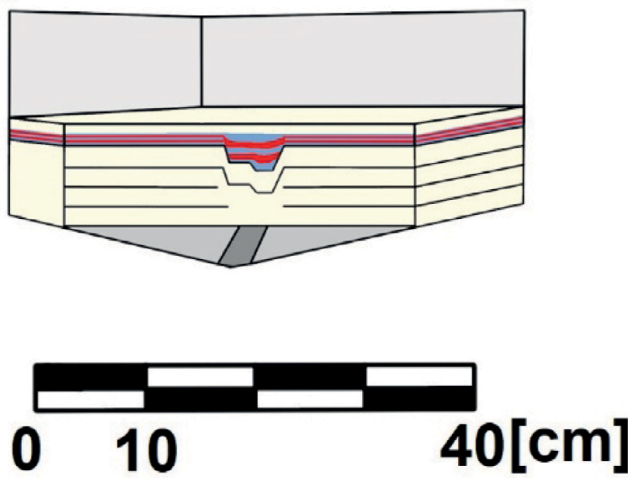

Figure 5. Schematic representation of Models 1 and 2. (A) Initial architecture of Model 1, before sedimentation. Direction of deformation indicated by black arrow (I) Motor (II) Lead support to maintain the integrity of the walls; (B) Cross-section representing an idealized cut made orthogonal to the structure created on the acetate sheet (C) Initial architecture of Model 2. Direction of deformation indicated by the black arrow (D) Cross-section representing an idealized cut made orthogonal to the structure created on the acetate sheet. 
transcurrent movement principally activated and reactivated the edge faults established in the extensional phase.

Cuts were made in a similar manner to that previously presented, and the sections were photographed for interpretation.

The Table 1 synthesizes the geometric and kinematic parameters used for all the models.
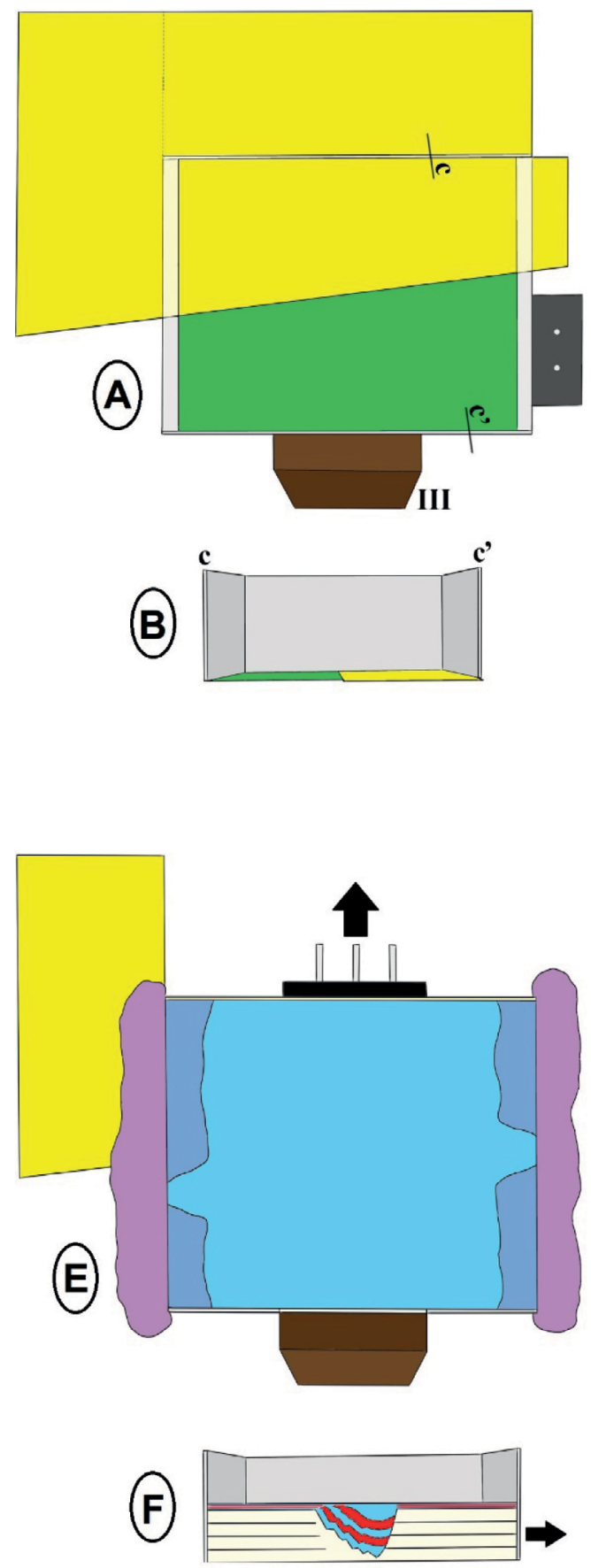

\section{RESULTS}

This section presents a selection of top-down photos taken during and after the deformation of the models, and cross-sectional photos taken after deformation of the models. Cuts were selected based on their representativeness, whereas the top down images were chosen to illustrate the undeformed basement, the
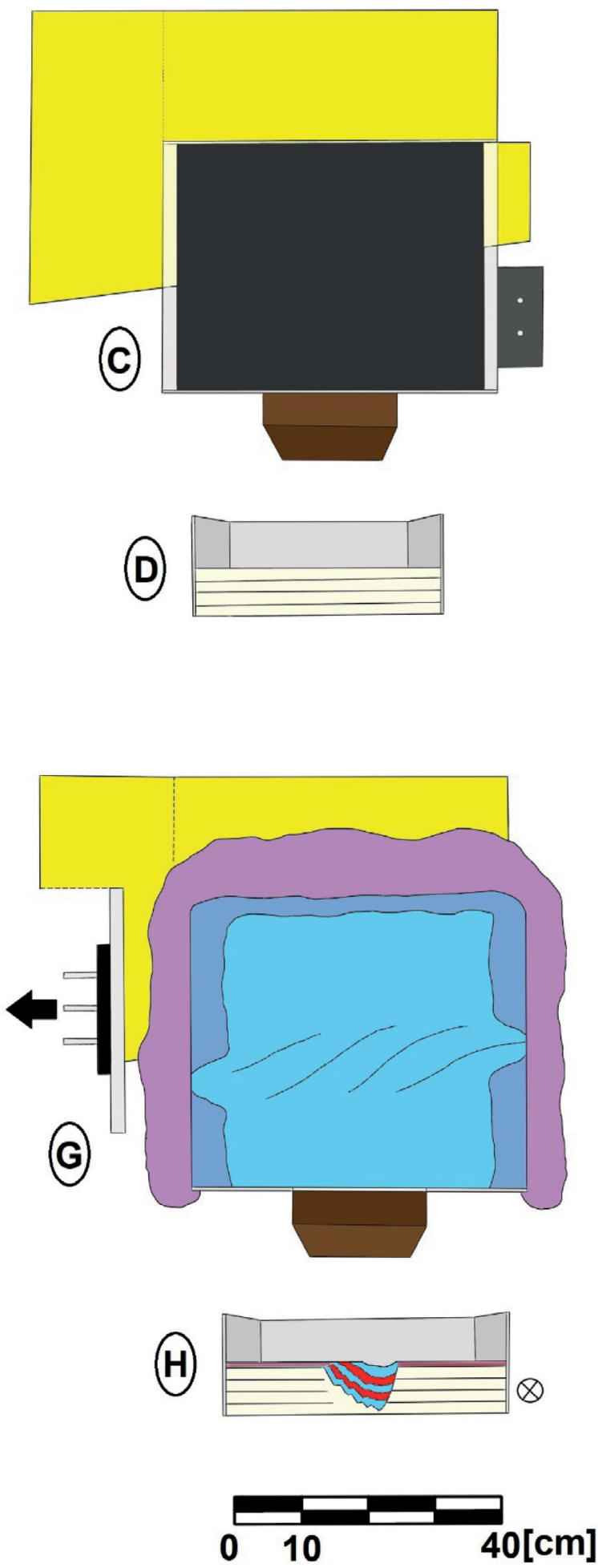

Figure 6. Schematic representation of Model 3. Respectively top and side views (A-B) of the initial architecture of Model 3 before sedimentation. The brown structure (III) is a wood support used to maintain the integrity of the wall. Respectively top and side views (C-D) of the final undeformed basement layer. Top and side views (E-F) after the end of the first phase of deformation by oblique asymmetric extension ( $5 \mathrm{~cm}$ of displacement). The purple borders represent the humid sand barriers previously mentioned. Top and side views (G-H) after the end of the second deformation phase by superposition of a sinistral transcurrent movement $(2.5 \mathrm{~cm}$ of displacement $)$. 
moment before each syn-deformational sedimentation, and the resulting surface at the end of the experiment.

\section{Model 1}

The first image illustrates the model's undeformed surface (Fig. 7A). During the first stage of deformation $(1 \mathrm{~cm})$ (Fig. 7B), en-echelon fractures were observed conformable to the structure imposed on the acetate sheet, characterized as the rift's edge fractures. The fault segments that will later compose the rift's main fault were located above the extremity of the acetate sheet coupled to the motor. These structures were more discontinuous than those identified on the opposite side and were concave towards the interior of the basin. At $2 \mathrm{~cm}$ of displacement enforced by the engine (Fig. 7C), the fault segments that localized the principal fault of the rift connected to form larger and more continuous structures. Meanwhile, other structures are generated, with different strikes than the faults that limited the initial rift. These structures were identified both inside and outside the rift system. When external to the rift, these structures were limited to the portion of the model upon the acetate sheet coupled to the motor. The cause of their absence on the other portion of the model is probably because it remained immobile during deformation. These structures were continuous over 5 to $10 \mathrm{~cm}$ long, and orthogonal to the engine displacement pathway.

With the progressive deformation (Figs. 7D, 7E, and 7F), the faults migration towards the interior of the rift occurred along both sandbox lateral limits. Discontinuous and slightly stepped sections broke parallel to the principal fault. The distance between these structures and the principal fault varied along strike, forming apparent terraces with a constant thickness. On the "flexural" margin, the disappearance of some

Table 1. Main scaling parameters of each model.

\begin{tabular}{|c|c|c|c|}
\hline Parameter & Model 1 & Model 2 & Model 3 \\
\hline \multicolumn{4}{|c|}{ Initial dimensions $(\mathrm{cm})$} \\
\hline $\mathrm{X}$ & 35 & 35 & 37 \\
\hline $\mathrm{Y}$ & 37 & 37 & 50 \\
\hline $\mathrm{Z}$ & 7.2 & 7.2 & 7.2 \\
\hline Horizontal scale & $1: 100,000$ & $1: 100,000$ & $1: 100,000$ \\
\hline Vertical scale & $1: 50,000$ & $1: 50,000$ & $1: 50,000$ \\
\hline $\begin{array}{l}\text { Applied } \\
\text { deformation }\end{array}$ & $\begin{array}{c}\text { Asymmetric } \\
\text { oblique } \\
\text { extension }\end{array}$ & $\begin{array}{c}\text { Relative } \\
\text { sinistral } \\
\text { trantension }\end{array}$ & $\begin{array}{c}\text { Asymmetric } \\
\text { oblique } \\
\text { extension } \\
\text { + sinistral } \\
\text { transcurrent } \\
\text { movement }\end{array}$ \\
\hline $\begin{array}{l}\text { Engine } \\
\text { displacement }(\mathrm{cm})\end{array}$ & 5 & 2.5 & $5+2.5$ \\
\hline $\begin{array}{l}\text { Engine } \\
\text { displacement } \\
\text { rate }(\mathrm{mm} / \mathrm{h})\end{array}$ & 20 & 20 & 100 \\
\hline \multicolumn{4}{|c|}{ Final dimensions $(\mathrm{cm})$} \\
\hline $\mathrm{X}$ & 40 & 37.5 & 42 \\
\hline $\mathrm{Y}$ & - & - & 52.5 \\
\hline $\mathrm{Z}$ & - & - & - \\
\hline
\end{tabular}

structures indicate that the early faults that controlled this portion of the rift stopped accommodating deformation and were subsequently covered by syn-tectonic sediments. The continuity of the structures in the final stages of deformation increased, due to the interconnection of early fault segments. Orthogonal structures relative to the applied displacement and external to the rift were no longer visible in plan view.

The opening of the rift reached $11 \mathrm{~cm}(11 \mathrm{~km}$ at scale) along the surface. In cross-sections 7 and 14 (Figs. $7 \mathrm{G}$ and $7 \mathrm{H})$ the migration of faults towards the interior of the basin is visible, especially those along the "flexural" margin, resulting in a gently dipping geometry with progressive deepening in the direction of the principal fault. The largest faults maintained a similar geometry principally high angle with a tendency towards lower angles at the top and base. The geometry of the inferior portions of the faults must not be considered in reason of the bias induced by friction against the base of the box, which also limited their propagation. In general, these faults present a vertical displacement between 1 and $2.5 \mathrm{~cm}$ (50 to $125 \mathrm{~m}$ at scale). The principal fault reached vertical displacements greater than $4 \mathrm{~cm}$ in some cuts (200 $\mathrm{m}$ at scale).

Some of the faults identified outside the rift were also interpreted in the cross-sections adjacent to the principal fault. They are characterized by their straight linearity (i.e., there are no variations in their dip) and small vertical displacement.

Smaller, antithetic faults were identified as nucleating from the major faults. They occasionally tilted the sediments adjacent towards the major faults. Other synthetic faults dissipated stress from the faults where they were nucleated.

Hanging wall synforms were analyzed close to the fault planes of the rift margin. Preservation of the original thickness of sedimentary beds close to the fault's plane is associated with the most internal faults of the basin. Thus, the greatest thicknesses of the sedimentary register $(200 \mathrm{~m}$ at scale — thickness relative to the top of the basin) are not always associated with the principal fault, but with portions of the most interior part of the rift, mainly in the sections where there was dismembering and branching from the principal fault to form terraces that were persistent in the geometry of the basin.

\section{Model 2}

The first image illustrates the model's undeformed surface (Fig. 8A). In this model, the first register of en-echelon faults occurred at $0.5 \mathrm{~cm}$ of displacement (Fig. 8B). After $1 \mathrm{~cm}$ (Fig. 8C), the early depocenters were individualized and highlighted in plan view of the model. The stepping faults that limited the rift were rectilinear and discontinuous. Oblique structures intercepted these faults at angles of approximately $20^{\circ}$. These structures compartmentalized the sedimentation and exhibited convexity towards the acetate sheet that was tensioned by the motor. In this phase, the coupling in some regions of these structures sectioned the rift with those that limited it. The model up to this stage resembled a complex of rhombohedral basins. When the displacement reached $1.5 \mathrm{~cm}$ (Fig. 8D), the connection between the depocenters was established. Some structures that limited the rift became 


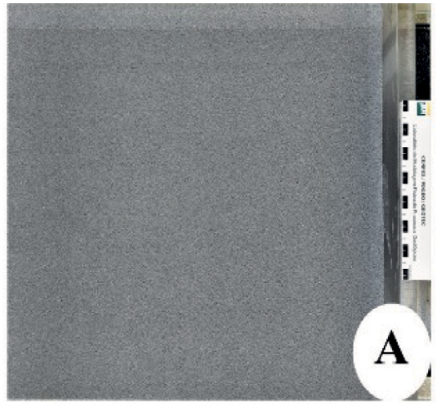

Undeformed

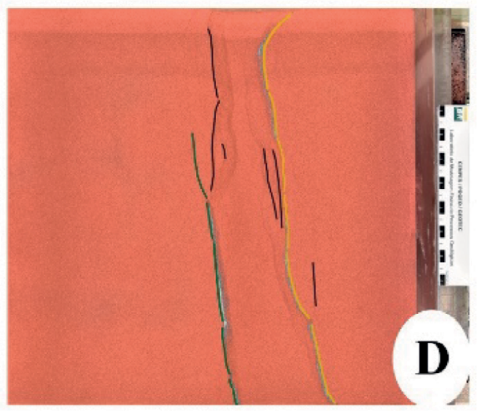

$3 \mathrm{~cm}$

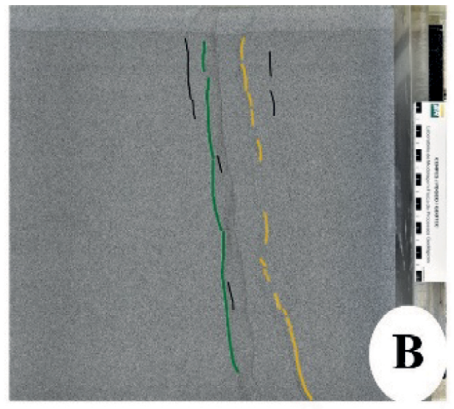

$1 \mathrm{~cm}$

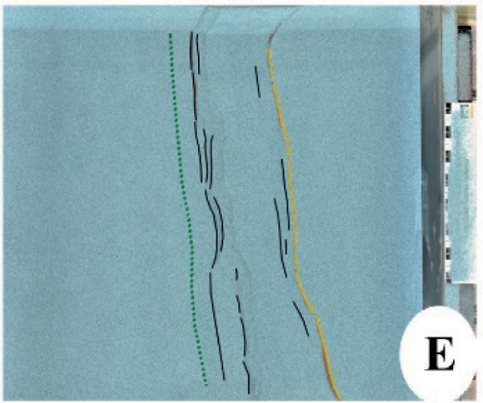

$4 \mathrm{~cm}$

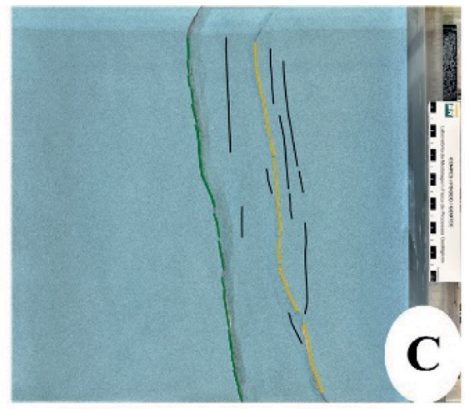

$2 \mathrm{~cm}$
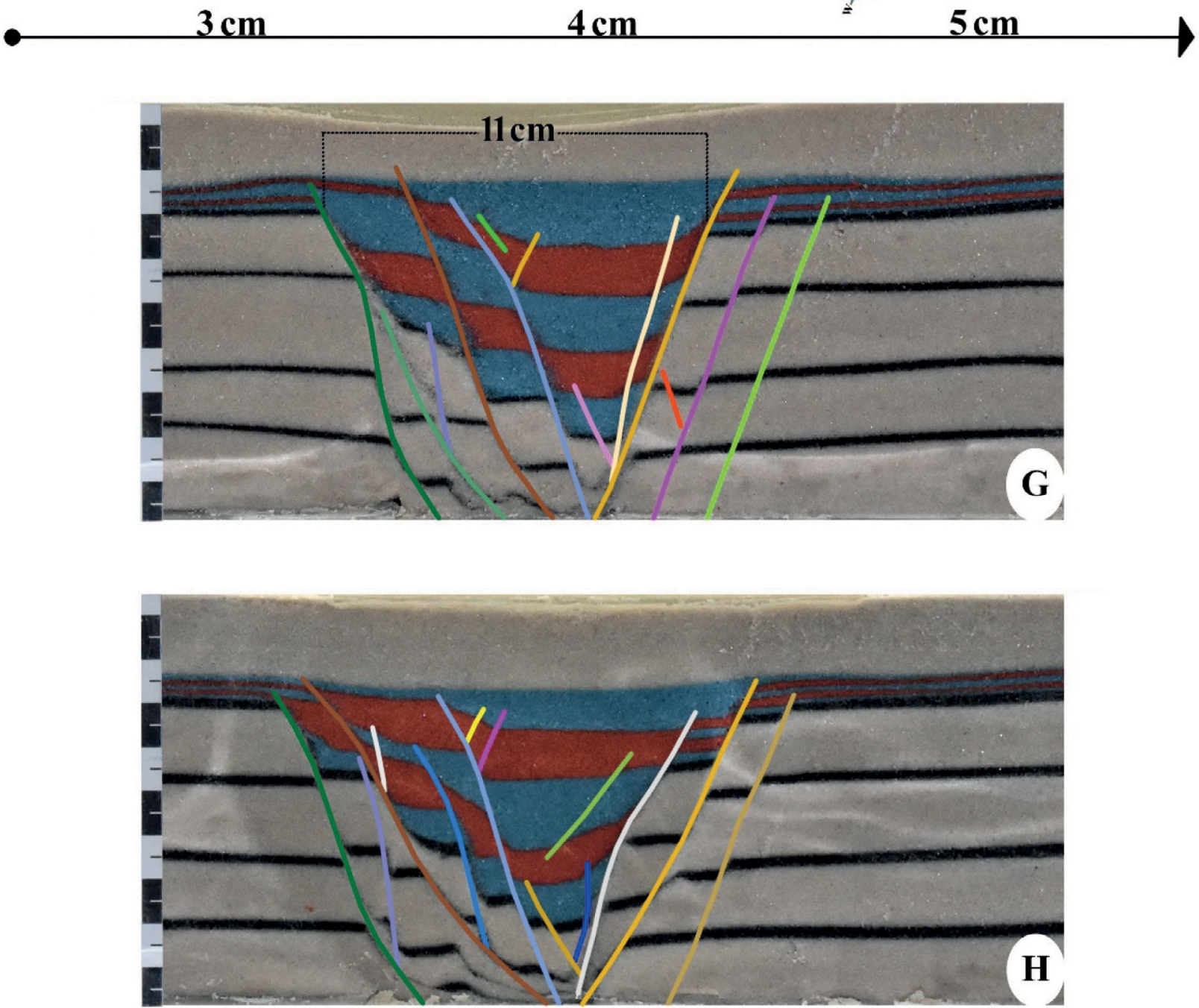

Figure 7. (A-F) Images of the plan view of Model 1. Images represent the increasing opening in intervals of $1 \mathrm{~cm}$ between them. (F) Plan view of model after a total of $5 \mathrm{~cm}$ of deformation, before the deposition of the final blue layer. The compass rose indicates the position of the model according to the prototype. The faults that limit the rift are highlighted by colored traces in plan view according to the color palette adopted for the section interpretations. The dark green dashed line illustrates a hypothetical surface extension of the principal fault on the "flexural" margin, which was no longer active in the final stages of deformation and became covered by sand. In detail, the location of sections $\mathrm{G}$ (Section 7) and H (Section 14). The right side of the section is couple to the moving wall. 
concave in the direction of the depocenter, principally in its central portions. The structures that compartmentalized the rift were poorly pronounced, but still indicated activity during this phase of deformation. This configuration persisted until $2 \mathrm{~cm}$ of deformation (Fig. 8E).
At the end of deformation (Fig. 8F), there is a clear union between the depocenters to form a unique and continuous basin. Despite their unification, the discontinuity of the marginal faults of the rift and the attitude of some of these structures are similar to the previous phases, when the depocenters

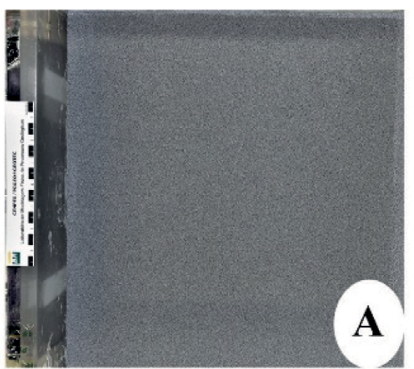

Undeformed

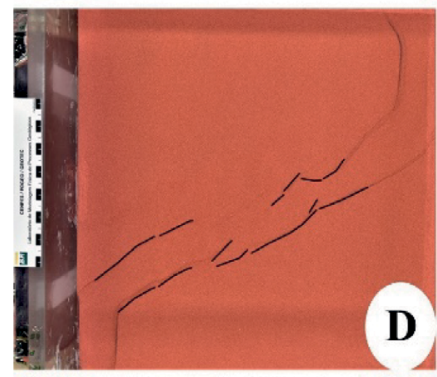

$1.5 \mathrm{~cm}$

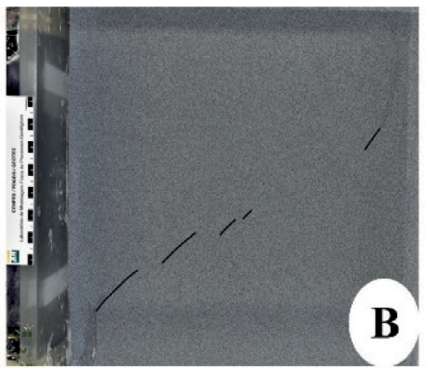

$0.5 \mathrm{~cm}$

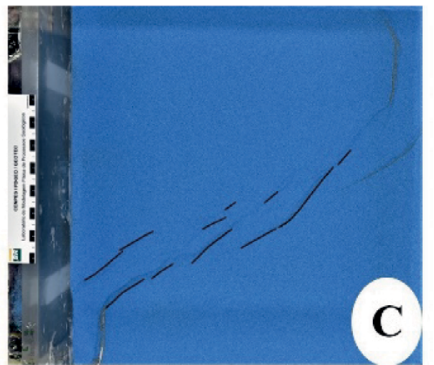

$1 \mathrm{~cm}$

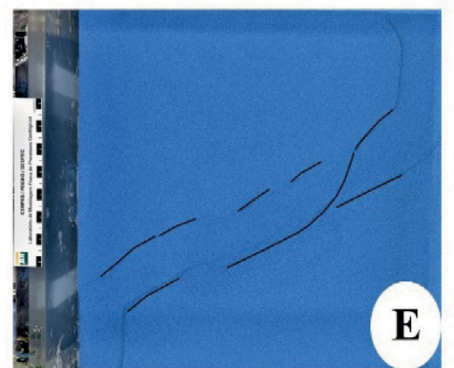

$2 \mathrm{~cm}$
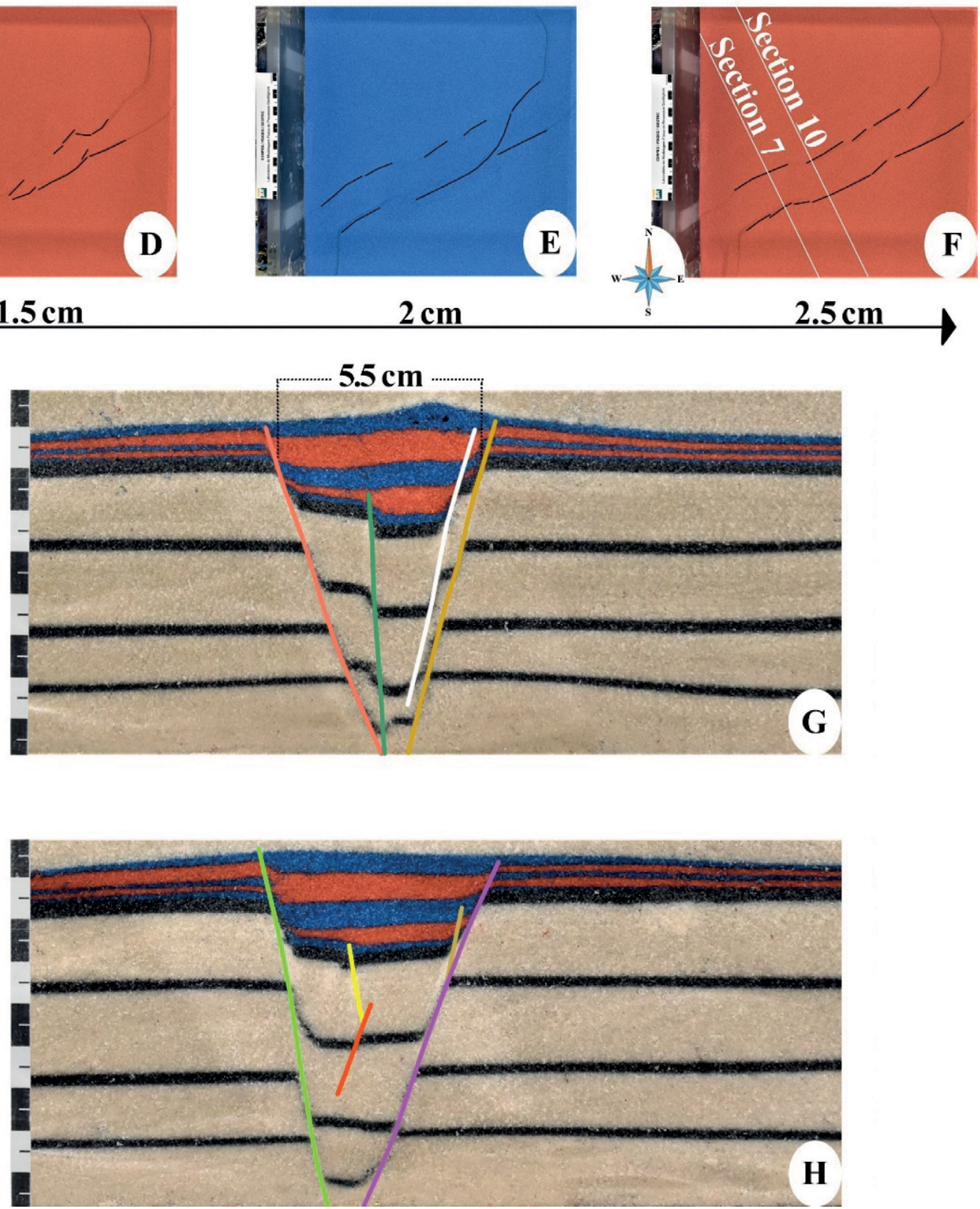

Figure 8. (A-F) Plan view images of Model 2. Images represent increasing deformation, with intervals of $1 \mathrm{~cm}$ between them. (F) Plan view of model after a total of $2.5 \mathrm{~cm}$ of deformation, before the deposition of the final blue layer. In detail, the location of sections $\mathrm{G}$ (Section 7) and $\mathrm{H}$ (Section 10). The compass rose indicates the position of the model according to the prototype. The left side of the sections are located closest to the mobile wall. 
were disconnected. In general terms, fewer structures were identified in plan view after the deformation than in the previous model at the same phase.

Intense remobilization of sediments (i.e., sand transportation from outside the rift towards its interior) was not observed along the marginal faults of the basin, nor was the migration of structures toward the depocenters, as observed in Model 1. The migration of structures, however, could have been prevented by the short interval of syntectonic sedimentation.

The highlighted sections (Figs. $8 \mathrm{G}$ and $8 \mathrm{H}$ ) show that the shallowest portions of the depocenter reached little more than $1 \mathrm{~cm}$ depth (50 $\mathrm{m}$ at scale). This model showed less deformation compared with the first model (50\%), and reached a depth approximately $75 \%$ smaller than Model 1 . In terms of opening, the resulting basin of this experiment was about half as wide as that of the previous experiment (i.e., $5.5 \mathrm{~cm}$ or $5.5 \mathrm{~km}$ at scale) along the surface.

Analyzing each individual section of the model, the internal structures appears to be simpler comparing with Model 1. Nevertheless, as units of a basin that organized into one uniform depocenter during the final stages of deformation, it presents distinct characteristics in each cross-section. In some sections, it could be analyzed the basin ranging from somewhat asymmetrical (Fig. 8G) to rather symmetrical (Fig. 8H). In this context, the general geometry obtained from this model was undoubtedly more symmetrical than the previous one. Underneath the infilling sediments of the model, it was possible to distinguish features that resemble negative flower structures (Fig. $8 \mathrm{H}$ ).

\section{Model 3}

The previously presented experiments and interpretations were used as a foundation for a better understanding of the structures generated in Model 3. Thus, the applied engine displacements were adjusted to reflect those of Models 1 and 2 (i.e., $5 \mathrm{~cm}$ of initial extension superimposed by $2.5 \mathrm{~cm}$ of sinistral transcurrent movement). The surface images of this model were oriented according to the structures of the prototype, which differs from the previous models (Fig. 9A-9F).

In general, the model responded predictably during the initial oblique asymmetric opening. During the initial stages of deformation $(1 \mathrm{~cm})$ (Fig. 9A), continuous coupled and slightly stepping structures were observed in plan-view, which evolved above the extremity of the cardboard sheet coupled to the motor. These structures defined the most active edge faults of the rift. They varied between rectilinear to concave towards the basins. Their orientations reflected the geometric impression of the cardboard sheet, with small local variation where they obtained a smaller obliquity in relation to the imposed engine displacement. On the adjacent margin, discontinuous and modest structures delimited the "flexural" margin of the basin. In this region, migration of structures towards the interior of the basin was observed beginning in the preliminary stages of deformation (Fig. 9B).

With progressive deformation (Figs. 9C and 9D), the structures became gradually more discontinuous. The migration of structures towards the interior of the basin was identified on both margins. However, this migration was more discontinuous and with greater distances between structures along the "flexural" margin of the rift. Structures convex towards the interior of the basin were common along this margin.

The faults that limited the "flexural" margin of the rift remained active until late stages of deformation. At $5 \mathrm{~cm}$ of opening (Fig. 9E), however, only those faults that were located closest to the interior of the basin remained active. At this stage of deformation, the faults acquired greater continuity due to the connection between previously disconnected segments.

Before the superposition of the extensional regime by a strike-slip one, a final layer of blue sand was uniformly distributed across the static model. This was to facilitate the identification of structures reactivated or generated during the second phase of deformation.

The imposed deformation reactivated the structures along the principal margin of the rift (Fig. 9F). These structures became more discontinuous, coupled, slightly stepping, and concave towards the basin interior. At their extremities, they developed an intermediate orientation between the previously established orientation and the newly applied displacement.

Smaller structures were identified above the previous "flexural" margin. These structures were more discontinuous, but maintained the geometry and attitude of the faults generated in the extensional phase.

The most distinct structures observed at the end of this phase were oblique to the rift. Four continuous and curved faults were easily identified, but the attitudes of some of these structures were masked by the cascade effect provoked by the removal of the walls (i.e., the remobilization of sediments at the extremities of the rift). Comparing to the prototype, these faults matches with the NE-SW normal faults described by Riccomini (1989) and Negrão (2014) generated during the Neogene (TS).

The structures described in the previous paragraph have other peculiarities that includes the continuous connection, or high-angle truncation against the structures that limit the rift. When connected, these structures are concave towards the "flexural" margin, similar to the structures that delimited the basin. When truncating, the concavity of these structure is directed towards the principal margin or, in this case, towards the cardboard sheet that was moved by the motor.

The structures generated in the second phase of deformation of Model 3 had similar attitudes as structures that compartmentalized the basins in Model 2. This characteristic corroborates the assumption of this experiment that a small variation in the angle of the engine displacement would not invalidate the model.

A hierarchy for the structures could be proposed when analyzing the cross-sections (Figs. 9G and 9H). The superior syntectonic blue layer served as a guide to identify the structures that were reactivated or generated during the second phase of deformation. As expected, the structures along the principal margin were those most reactivated during deformation, due to the relative movement of the cardboard sheet.

Superficial manifestations were also identified above the adjacent margin. These more recent structures had much smaller 

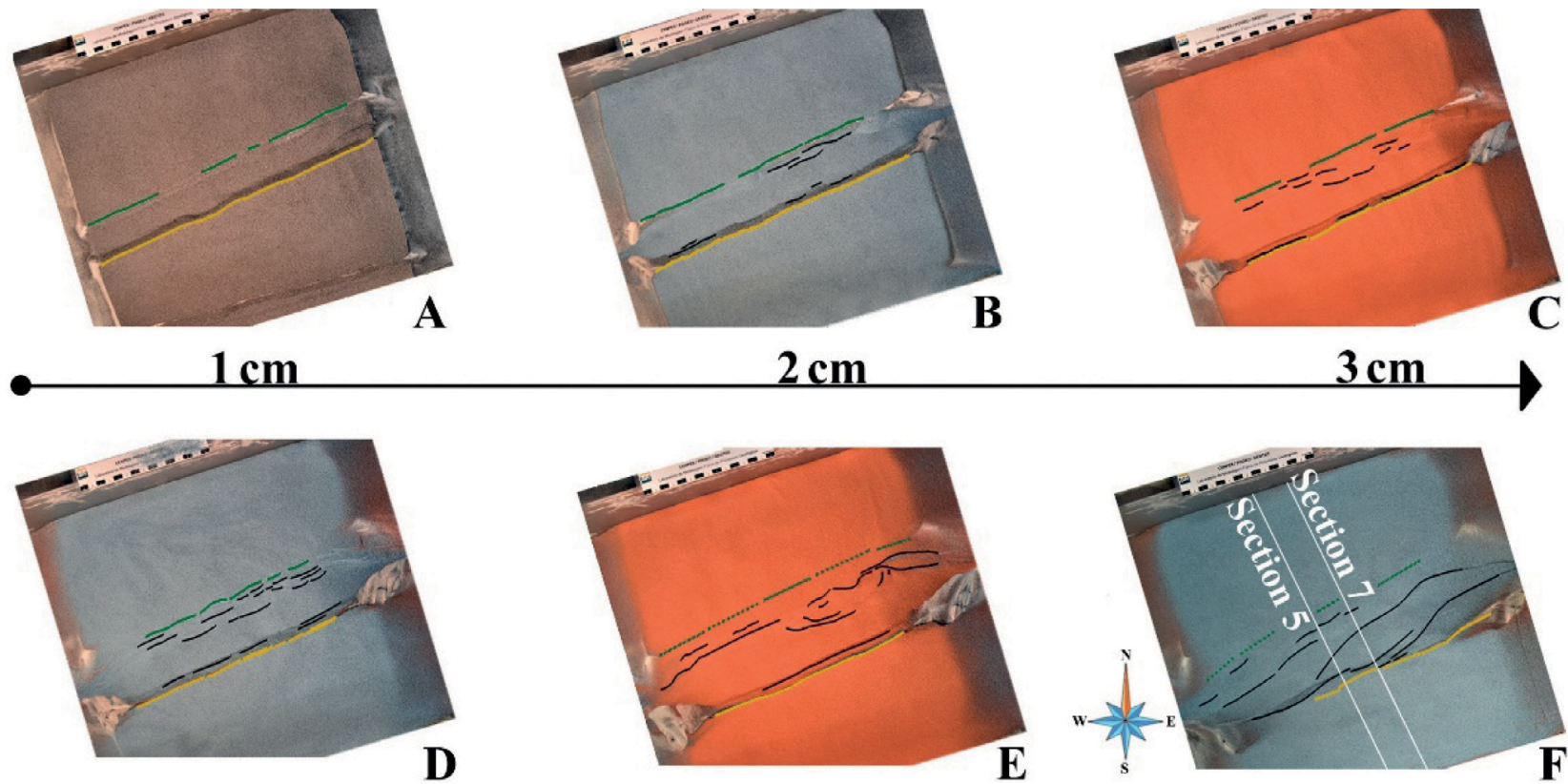

D

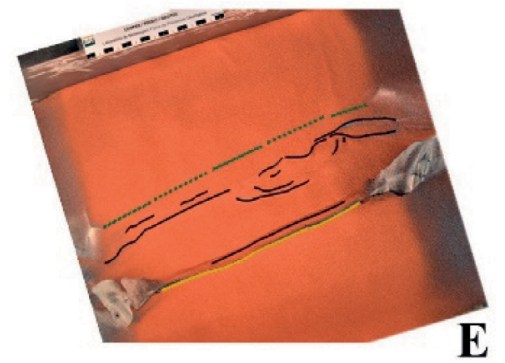

$5 \mathrm{~cm}$

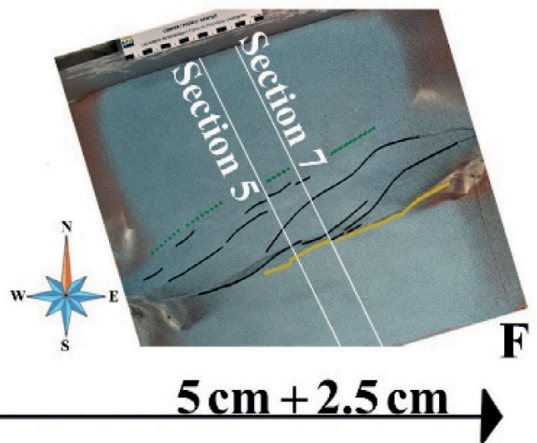

\section{$12.5 \mathrm{~cm}$}
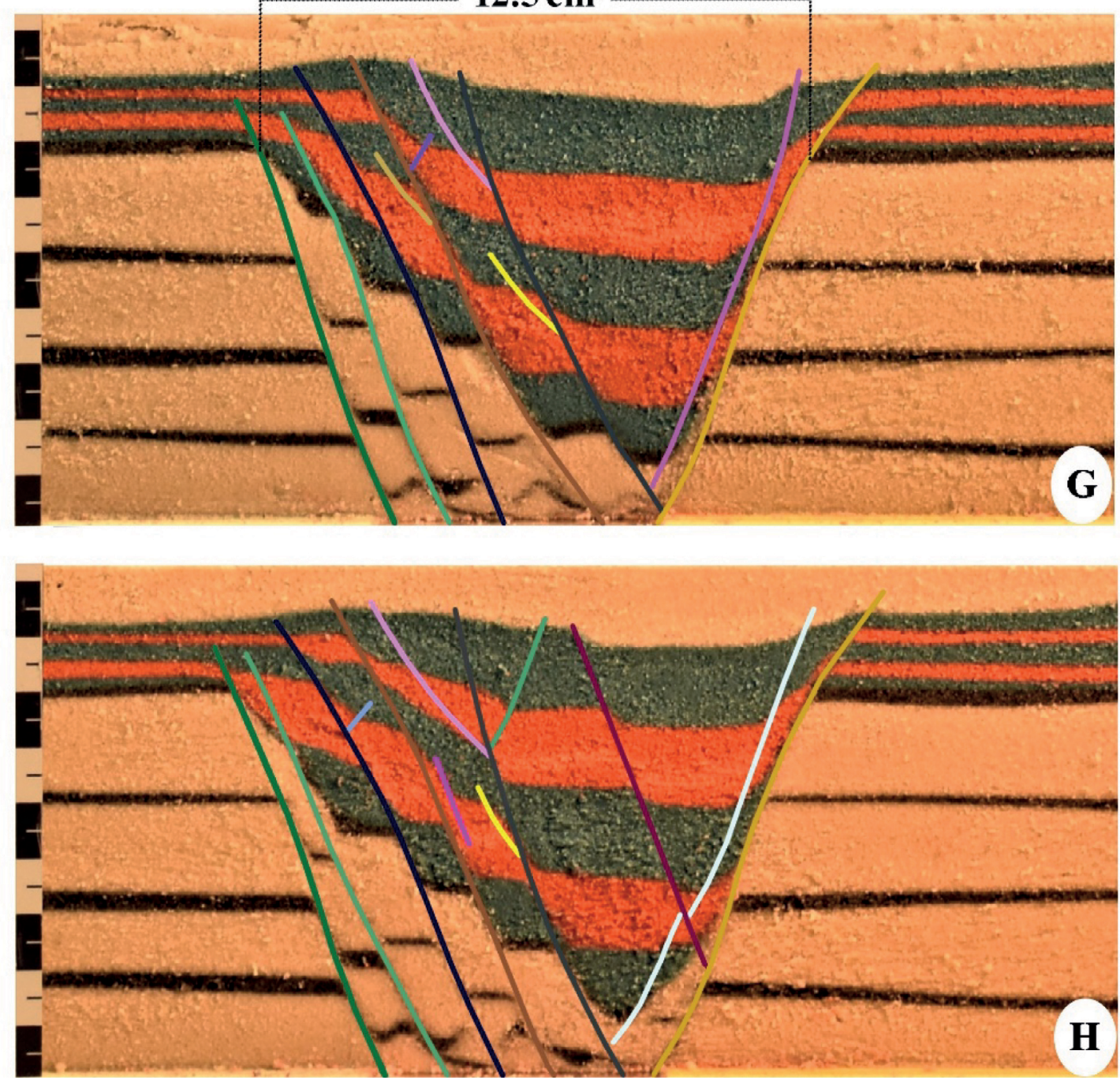

Figure 9. (A-E) Plan-view images of Model 3 during the first phase of deformation (i.e., asymmetric, oblique extension). Images are organized in an increasing order of deformation with intervals of $1 \mathrm{~cm}$ between them. (F) Plan-view of Model 3 after the superposition of $2.5 \mathrm{~cm}$ of oblique engine displacement. The faults that limit the rift are highlighted by colored traces in plan view according to the color palette adopted for the section interpretations. The dark green dashed line illustrates a hypothetical surface extension of the principal fault on the "flexural" margin, which was no longer active in the final stages of deformation and became covered by sand. In detail, the location of sections $\mathrm{G}$ (Section 5) and $\mathrm{H}$ (Section 7). The compass rose indicates the position of the model according to the prototype. The left side of the sections in plan-view are located closest to the mobile wall (NNE). Meridional illumination. 
vertical displacements than those attributed to extension (e.g., $0.5 \mathrm{~cm}$ on average, approximately $13 \mathrm{~m}$ at scale). In one of the cross-sections, it can be observed a normal fault that cut and detach segments of an anterior structure (Fig. 9H). One must emphasize that it wasn't applied any methodology to verify strike-slip component of movement of the faults described as normal faults in this section, but the resulting geometric pattern observed on it is pretty much compatible with the expected for this type of geological environment

The final thickness of the basin, as well as its aperture, were greater in Model 3 than in the previous models. In addition, it is possible to analyze in the cross sections that there are potential local uplifts on the surface, especially on the left side of the cross sections.

A greater structural complexity was provoked by the smaller faults that nucleated on the structures formed during the opening phase (Fig. 9H). In this section, one of these small structures resulted in the uplift of a small horst on the surface.

\section{DISCUSSION AND CONCLUSION}

Considering the main objective of this study was to describe the structural evolution resulting from the superposition of a phase of low-angle extension (i.e., strike slip movement) over a phase of high-angle extension, both identified in the Volta Redonda Basin, analogue modelling has proved itself a convenient and reasonable methodology to characterize the proposed tectonic evolution and its associated structures.

The resulting geometry of Model 1 partially reflected the configuration proposed by Negrão (2014) and Negrão et al. (2015) for Volta Redonda Basin during the Paleogene. On the other hand, the resulting geometry of Model 2 is not consistent with any of the configurations proposed by the conceptual models. In this context, it's been verified that one single tectonic event is not capable of reproduce the current structural configuration proposed for the basin. Despite both models did not fully represent the configurations proposed by Negrão (2014) and Negrão et al. (2015), they integrated the theoretical base for the interpretation of the subsequent Model 3 once the same boundary conditions were adopted during its development.

On the subject of Model 3, the superposition of the strikeslip regime over the extensional regime exposed the importance of structural reactivation, particularly along the principal margin of the basin. The consequent structural framework along the principal margin, which was formerly continuous, became stepped and discontinuous, as proposed by Negrão et al. (2015) for the Cenozoic sedimentary accumulations of the Volta Redonda Basin in its current configuration.
The greater thickness and aperture produced in Model 3, if compared with the previous models, might be related to the superposition of the subsequent tectonic phase. Another hypothesis is that the stablished architecture for this model could have interfered in its genesis. A question of great concern is about the local uplift observed on the surface of Model 3. Although its resolution might not be adequate to interpret properly this structure, it could be an indication of local inversion over an area coincident to that located northwestward from the Alto de Jardim Amália, predicted by conceptual models. Another less likely hypothesis is that the sedimentation process that took place on the models during the first phase of deformation was heterogeneous on this spot.

Some minor yet distinct structures were observed on the Model 3 top surface as a result of reactivation and generation of structures after the superposition of the second phase of deformation (Fig. 9H). These structures potentially match with internal highs identified within the basin with a preferential NE-SW orientation. Finally, it should be emphasized that it's quite possible that the pattern of nucleation of faults and fault reactivation could have been altered due to the absence of ways to faithfully simulate isostasis, erosion and concurrent sedimentation, representing a limitation of analogue modelling and preventing it to expose even more striking similarities.

The distribution and kinematics of the structures generated during the modelling of both deformation phases, related to the introduced basement discontinuity and to the displacements applied by the motors, match with the general structural aspects (i.e., basin geometry, fault pattern, fault orientation etc.) identified in field study by Negrão (2014) and Negrão et al. (2015). Despite the lack of ways to prove the strike-slip movement of the faults by the applied methodology, the attitude of the oblique faults generated during the second phase of deformation match with the NE-SW normal faults described in the literature for Volta Redonda Basin. Considering all this, the results allow us to state that the originally proposed conceptual model proposed by these authors is coherent and, therefore, possibly closely represent the reality.

\section{ACKNOWLEDGMENTS}

I would like to thank CAPES for my master's scholarship. I also thank the Universidade Federal Fluminense (UFF) for the structure that allowed my studies. My colleagues at UFF/GISIS for their shared knowledge. Finally yet importantly, I thank Petrobras for the access granted to its Geological Processes Modelling Laboratory where all the models were conducted.

\section{ARTICLE INFORMATION}

Manuscript ID: 20190129. Received on: 12/10/2019. Approved on: 06/03/2020.

A.R. made all the practical experiments, wrote the first draft of the manuscript and prepared all the figures; M.S. improved the manuscript through corrections and suggestions; A.S. improved the manuscript through correction and suggestions, guidance throughout the practical experiments and transmitted the required geological knowledge to accomplish the goal of the study; F.L. improved the manuscript through correction and suggestions and guidance throughout the practical experiments; S.N. guidance throughout the practical experiments.

Competing interests: The authors declare no competing interests. 


\section{REFERENCES}

Almeida F.F.M., Hasui Y., Neves B.B.B., Fuck R.A. 1981. Brazilian structural provinces: an introduction. Earth-Science Reviews, 17(1-2):1-29. https:// doi.org/10.1016/0012-8252(81)90003-9

Brêda T.C., Mello C.L., Moraes A. 2018. Significado tectônico de padrões de lineamentos na porção emersa das bacias marginais do sudeste do Brasil e áreas de embasamento adjacentes. Anuário do Instituto de Geociências, 41(3):305-318. https://doi.org/10.11137/2018_3_305_318

Cappelletti A., Tsikalas F., Nestola Y., Cavozzi C., Argnani A., Meda M., Salvi F. 2013. Impact of lithospheric heterogeneities on continental rifting evolution: Constraints from analogue modelling on South Atlantic margins. Tectonophysics, 608:30-50. https://doi.org/10.1016/j.tecto.2013.09.026

Carvalho T.S. 2017. Physical models of two-phase extensional basins and comparison with natural examples. MS Dissertation, Universidade Federal de Ouro Preto, Ouro Preto, $171 \mathrm{p}$.

Clemson J., Cartwright J., Booth J. 1997. Structural segmentation and the influence of basement structure on the Namibian passive margin. Journal of the Geological Society, 154:477-482. https://doi.org/10.1144/gsjgs.154.3.0477

Cobbold P.R., Meisling K., Mount V.S. 2001. Reactivation of an obliquely rifted margin, Campos and Santos basins, southeastern Brazil. AAPG Bulletin, 85(11):1925-1944. https://doi. org/10.1306/8626D0B3-173B-11D7-8645000102C1865D

Corti G. 2012. Evolution and characteristics of continental rifting: Analog modeling-inspired view and comparison with examples from the East African Rift System. Tectonophysics, 522-523:1-33. https://doi. org/10.1016/j.tecto.2011.06.010

Corti G., Bonini M., Conticelli S., Innocenti F., Manetti P., Sokoutis D. 2003. Analogue modelling of continental extension: a review focused on the relations between the patterns of deformation and the presence of magma. Earth-Science Reviews, 63(3):169-247. https://doi.org/10.1016/ S0012-8252(03)00035-7

Davy P., Cobbold P.R. 1991. Experiments on shortening of a 4-layer models of continental lithosphere. Tectonophysics, 188(1-2):1-25. https://doi. org/10.1016/0040-1951(91)90311-F

Heilbron M., Pedrosa-Soares A.C., Campos Neto M.C., Silva L.C., Trouw R.A.J., Janasi V.A. 2004. A Província Mantiqueira. In: Mantesso-Neto V., Bartorelli A., Carneiro C.D.R., Brito Neves B.B. (Eds.). Geologia do Continente Sul-Americano: Evolução da Obra de Fernando Flávio Marques de Almeida. São Paulo: Beca, p. 203-234.

Keep M., Harrowfield M. 2005. Basement reactivation and inversion mechanisms in the Timor and Norwegian seas. In: Dore A.G., Vining B. (Eds.). Petroleum Geology: North-West Europe and Global Perspectives-Proceedings of the 6th Petroleum Geology Conference London: Geological Society, p. 861-871. Petroleum Geology Conference series, v. 6. https://doi.org/10.1144/0060861

Maciel I.B. 2016. Caracterização da deformação rúptil em afloramento da Formação Resende, Bacia de Volta Redonda (estado do Rio de Janeiro). Dissertation, Instituto de Geociências, Universidade Federal do Rio de Janeiro, Rio de Janeiro, $80 \mathrm{p}$.

Maurin J., Guiraud R. 1993. Basement control in the development of the Early Cretaceous West and Central African Rift System. Tectonophysics, 228(1-2):81-95. https://doi.org/10.1016/0040-1951(93)90215-6
McClay K.R., Dooley T., Whitehouse P., Mills M. 2002. 4-D evolution of rift systems: Insights from scaled physical models. American Association of Petroleum Geologists Bulletin, 86(6):935-960.

McClay K.R., White M.J. 1995. Analogue modelling of orthogonal and oblique rifting. Marine and Petroleum Geology, 12(2):137-151. https://doi. org/10.1016/0264-8172(95)92835-K

Melo M.S., Riccomini C., Campanha G.A.C., Mioto J.A., Almeida F.F.M., Hasui Y., Ponçano W.L., Gimenez A.F. 1983. Estudos geológico-tectônicos na Bacia de Resende (RJ) e sedimentos terciários de Volta Redonda (RJ) e Bacia de Taubaté (área de Cruzeiro- SP). Relatório 17.737. São Paulo: IPT, 124 p.

Negrão A.P. 2014. Evolução tectonossedimentar e deformação rúptil cenozoica da região da bacia sedimentar de Volta Redonda (Segmento Central do Rifte Continental do Sudeste do Brasil, RJ). PhD Thesis, Instituto de Geociências, Universidade Federal do Rio de Janeiro, Rio de Janeiro, 249 p.

Negrão A.P., Ramos R.R.C., Mello C.L., Sanson M.S.R. 2015. Mapa geológico do Cenozoico da região da bacia de Volta Redonda (RJ, Segmento Central do Rifte Continental do Sudeste do Brasil): identificação de novos grábens e ocorrências descontínuas, e caracterização de estágios tectonossedimentares. Brazilian Journal of Geology, 45(2):273-291. https: // doi.org/10.1590/23174889201500020007

Padilha A.L., Vitorello I. 1992. Investigações geoelétricas nas bacias de Volta Redonda e Resende. In: Congresso Brasileiro de Geologia, 37., 1992. Resumos Expandidos. São Paulo, p. 403-404. v. 2.

Riccomini C. 1989. O Rift Continental do Sudeste do Brasil. PhD Thesis, Instituto de Geociências, Universidade de São Paulo, São Paulo, 256 p.

Riccomini C., Melo M.S., Carneiro C.D.R., Almeida F.F.M., Mioto J.A., Hasui Y. 1983. Sobre a ocorrência de um derrame de ankaramito na Bacia de Volta Redonda (RJ) e sua importância na datação das bacias tafrogênicas continentais do sudeste brasileiro. In: Simpósio Regional de Geologia, 4., 1983. Resumos... São Paulo: SBG, p. 23-24.

Riccomini C., Sant’Anna L.G., Ferrari A.L. 2004. Evolução geológica do Rift Continental do Sudeste do Brasil. In: Mantesso-Neto V., Bartorelli A., Dal Ré Carneiro C., Brito Neves B.B. (Eds.). Geologia do Continente SulAmericano: Evolução da Obra de Fernando Flávio Marques de Almeida. São Paulo: Beca, p. 383-405.

Rodrigues J.R.S.S. 2016. Modelagem 2D aplicada ao estudo do desenvolvimento de zonas de falha em depósitos da Formação Resende (Bacia de Volta Redonda, RJ). Trabalho de Conclusão de Curso (Graduação em Geologia), Universidade Federal do Rio de Janeiro, Rio de Janeiro, 39 p.

Sanson M.S.R. 2006. Sistemas deposicionais aluviais e tectônica cenozóica na região de Volta Redonda (RJ) - Rift Continental do Sudeste do Brasil. MS Dissertation, Instituto de Geociências, Universidade Federal do Rio de Janeiro, Rio de Janeiro, $151 \mathrm{p}$.

Sanson M.S.R., Ramos R.R.C., Mello C.L. 2006. Bacias Sedimentares Brasileiras: Bacia de Volta Redonda. Phoenix, 88:1-6.

Tong H., Koyi H., Huang S., Zhao H. 2014. The effect of multiple preexisting weaknesses on formation and evolution of faults in extended sandbox models. Tectonophysics, 626:197-212. https://doi.org/10.1016/j. tecto.2014.04.046 